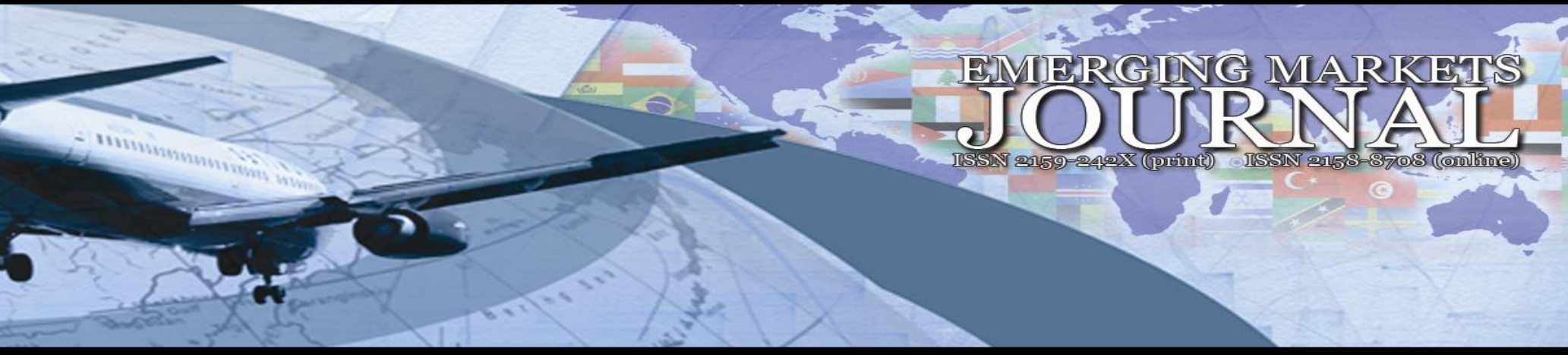

\title{
Market Dynamism and Firm Performance Relation: The Mediating Effects of Positive Environment Conditions and Firm Innovativeness
}

\section{Cemal Zehir}

Y1ldız Technical University, Turkey | czehir@yildiz.edu.tr

\section{Dilek Balak}

Beykent University, Turkey | dilekbalak@beykent.edu.tr

Volume 8 No 1 (2018) ｜ ISSN 2158-8708 (online) | DOI 10.5195/emaj.2018.152 | http://emaj.pitt.edu |

\begin{abstract}
There has been a great interest in terms of environment and its effects in the organization. Apart from environmental conditions, market dynamism is emphasized as another important factor that affects firm performance. Organizations have to compete to survive in a changing environment. In our study, we expected to find out significant relationship through dependent variables (operational performance and market performance) and independent variable as market dynamism. Another goal of our study is to reveal the mediation effects of positive environment conditions and firm innovativeness to firm performance. It should be noted that, our study is based on a survey distributed to 327 people who work in companies in Turkey and analysis results represented the mediating effects of positive environment conditions on firm performance. The obtained data from the questionnaires are analysed through the SPSS statistical packaged software. Further, we compared relationship among the factor analysis, reliability, correlations and regressions. Consequently, our hypotheses are supported and positively related.
\end{abstract}

Keywords: Market Dynamism, Positive Environment Conditions, Firm Innovativeness, Firm Performance

\section{$(c c)$ BY}

New articles in this journal are licensed under a Creative Commons Attribution 3.0 United States License.

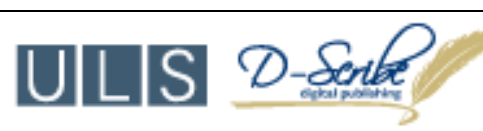

This journal is published by the University Library System of the University of Pittsburgh as part

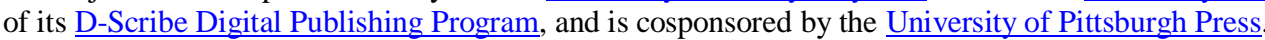




\section{Market Dynamism and Firm Performance Relation: The Mediating Effects of Positive Environment Conditions and Firm Innovativeness}

\section{Cemal Zehir \\ Dilek Balak}

\section{Introduction}

With globalization, it is observed that businesses need to consider factors such as manufactured good or service offered, market conditions and uncertainty. At the same time, the potential opportunities and threats that these factors bring with them also suggest that innovation may be another issue that concerns businesses.

In most of the organizational strategy research, the relationship between the two structures is better explained by looking at unexpected situations or moderator effects. Dynamism is expressed by $\mathrm{Li}$ and Simerly (1998) as an important moderator of the link between organizational decisions and outcomes. In numerous studies on organizational theory, environmental uncertainty is defined as an important determinant of the relationship between organization and performance (Homburg et. al., 1999, p. 344). Since environmental uncertainty is a multi-dimensional structure, dynamism has been focused on as an important component of environmental uncertainty in this study.

The richest courses of research in organizational theory has centered on organization- environment relations. Because, environment provides restricts and opportunities for organizational action (Tushman and Anderson, 1986, p. 439). The organizational environment is operationalized in ways that are consistent with the population-ecology and resource-dependence conceptualization of the interplay of organization and external environment. Both the resource-dependence and population-ecology paradigms are resources required for organizational survival, which are the most important focus in describing organizational environments (Dess and Beard, 1984, p. 52). Most of the previous studies have focused on one aspect of the environment, namely uncertainty or rate of change. However, there are two critical aspects of the environment in which a firm is operating, such as relatively less noticeable complexity and uniformity (Ting, Wang and Wang, 2012, p. 517). According to Dess and Beard (1984), the significant three dimensions of the organizational environment are dynamism (stability-instability), munificence and complexity (homogeneity-heterogeneity). In this study, organizational munificence as the positive environmental conditions is tried to be addressed.
Environmental possibilities is seen as a multidimensional construct, that involve dynamism, technological opportunities, industrial growth, and demand for new products. Dynamism and technological opportunities are two environmental features for innovation. Dynamism refers to perceived instability and constant changes in the company's markets. Increased dynamism is seen as favorable to innovation as it tends to create opportunities in a company's markets. Organizations often adopt an innovative stance to respond to challenging conditions in dynamic or hightech environments. It is thought that, the competitive nature of the sector, environmental changes and basic technologies are influencing innovativeness (Antoncic and Hisrich, 2001, p. 503). Nevertheless, in markets with dynamic structure, the findings of the applied studies reveal that firms focus more on innovation applications (Thornhill, 2006, p. 687; Cadogan et. all., 2009, p. 75).

Innovation strategy is a key indicator of firm performance. Organizational innovation is the application of a new organizational method in practical, organizational or external relations of the firm. Organizational innovation improves firm performance by reducing administrative and transaction costs, and at the same time increases workplace satisfaction (Rajapathirana and Hui, 2018, p. 46). Businesses always try to formulate the right competitive strategy to ensure optimal business performance. Such an effort is also important for a company not only to survive, but also to become a competitive company in the business environment.

On the other hand, a significant amount of research has shown that organizational innovation is positively related to performance and provides a competitive advantage for the firm (Rubera and Kirca, 2012, p. 130; Thornhill, 2006, p. 687; Gunday et. al., 2011, p. 662). In a study conducted in Iran, the relationship between organizational innovation and performance was researched and it was found out that, innovation has a positive and significant effect on the financial and organizational performance (Rajapathirana and Hui, 2018, p. 49).

In our research, considering the structure of the industry and the competition environment, positive environment conditions and market dynamism as environmental elements and firm innovativeness as organizational elements were discussed. Also, it was aimed to examine the effects of these variables on performance of the firm. In the study, firstly a conceptual framework was established, research hypotheses were revealed, then the collected data were subjected to the analysis process and finally research findings were discussed and a number of suggestions for researchers were presented.

\section{Literature Review and Theoretical Framework}

\subsection{Market Dynamism}

Dynamism refers to the degree of uncertainty in market and industry conditions, including the state of technology and general economic performance. This indicates that, some innovations have to be made to maintain competition for companies in dynamic 
industries. Many research in the literature indicate that environmental dynamism is positively related to innovation (Thornhill, 2006, p. 690). High market dynamism describes the environment in which changes often take place, but the direction and consequences of this change are unpredictable. A dynamic market can affect the effectiveness of the firm's behavior. A dynamic market is emerging when changes in the behavior of market players are considered important to a company. In addition, changes in the behavior of competitors arise quickly and uncertainly. Changes in customer behaviors are difficult to predict. But, the needs and expectations of them for a product can change very easily. In such a market, the effectiveness of a company's behavior is based on more recent information except for is available information. Because, market dynamism can offer new and broader perspectives that will help to solve the firm's problems and capture new opportunities. High market dynamism ensures that firms are more sensitive to environmental changes. In this case, business process becomes more effective by using new information (Ikhsan et. all., 2017, p. 374).

Strategic management considers the environment as an important contextual factor with a strong influence on a company's strategic direction. Moreover, the strategy literature supports the view that both firm owners and senior executives must deal with the impact of environment ( $\mathrm{Li}$ and Simerly, 1998, p. 169).

For example, Gatignon and Xuereb (1997) show that, under the conditions of high-level market dynamism, firms have become more interested in technological trends and that the relationship between technological orientation and business success has become stronger. Similarly, Lumpkin and Dess (2001) state that, innovation orientation is more closely related to business success in the context of increased dynamism, and that the relationship between innovation propensity and performance is stronger when the level of dynamism is higher (Cadogan et. al., 2009, p. 75). Our hypothesis from these considerations is that, market dynamism has positive effects on firm innovativeness. In addition to this, it is also expected that innovativeness is a positive reflection of firm performance.

\subsection{Firm Innovativeness}

Innovation is seen as a fundamental component of competitive superiority. It is embedded in organizational structures, processes, products and services within an enterprise (Gunday et. all., 2011, p. 662). Factors such as demographic change, financial reforms, emerging market, changing customer behavior with the advancement of communication and information technology; has an important influence on shaping the structure of the industry, efficiency and productivity. This condition can create a very serious threat or opportunity. The ability to innovate allows the organization to innovate in a constantly changing market environment. At the same time, it requires that all strategies, systems and structures that support innovation in a company are included (Rajapathirana and Hui, 2018, p. 44). Certain environmental attributes, such as dynamism, technological opportunities, industry growth and demands for new products, are thought as positive variables for innovativeness (Antoncic and Hisrich, 2001, p. 503).

Innovativeness is considered a highly competitive market environment and a factor of success for the global economy. Firm's innovative perspective also provides information about the future position of the market (Rajapathirana and Hui, 2018, p. 44).

Innovativeness can only happen if the firm has innovative capacity (Laforet, 2011). Innovation capability is considered to be a valuable asset for companies to maintain competitive advantage and to implement the entire strategy (Lawson and Samson, 2001). The firm's ability to innovate makes it easier for firms to quickly introduce new products to the market and to adopt new systems. It is also seen as an important factor to feed ongoing competition. Innovative performance can be described as a combination of assets and resources. For this reason, a wide variety of resources, assets and skills are required to achieve success in a rapidly changing environment (Sen and Egelhoff, 2000). According to Adler and Shenbar (1990), innovation capability is defined as the ability to respond to market requirements of new products. In addition, innovation capacity is also described as the application capacity of appropriate process technologies to produce these new products and the capacity to develop and adopt new products and processing technologies to meet future needs; It is also referred to as the capacity to respond to competitive technology activities and unforeseen opportunities composed by competitors.

Company innovation is referred with two different perspectives. First point of perspective is innovation as a behavioral factor. That is the rate of adoption of innovations by the firm. Second perspective is the willingness of the organization to change (Calantone et al., 2002, p. 517). Auh and Menguc (2005) refers to firm innovativeness as a tendency for an organization to engage in innovative behavior.

The adoption of innovativeness is conceived to encompass the generation, improvement, and implementation of new opinions or behaviors. The adoption of innovation is generally intended to contribute to the performance of the organization. Innovation is a means of changing an organization, whether as a response to alterations in its internal or external environment. As even the most stable environments change, organizations adopt innovativeness in ordinary over time (Damanpour, 1991, p. 556).

\subsection{Positive Environment Conditions}

Some management academics have defined the organization as either flexible or turbulent, stable or uncertain, simple or complex, and static or dynamic. In general, a typical business environment is described in terms of uncertainty, complexity and munificence (Adegbite et. al., 2018, p. 12). For a long time, the environmental factors have been regarded as one of the critical elements of organizational theory and strategic management. Many conceptualizations of the 
environment are substantially consistent with Dess and Beard's (1984) three dimensions. These are munificence, complexity, and dynamism (Lumpkin and Dess, 2001, p. 436). In our study, we will handle the munificence dimension as an environmental factor.

Munificence (or resource availability) is a crucial ingredient of business environment. It refers to the scarcity or plenteous of key resources needed by firms operating within an environment. Environmental munificence manifests in the form of fast-growing markets, adequate infrastructure, lower taxes, competent workforce and national/global economic improvement (Adegbite et. al., 2018, p. 17). Munificence is usually considered to the extent, which an environment can provide adequate resources for the companies operating in it (Fuentes et. al., 2004, p. 427). Munificence may be assumed as the extent to which the environment can support growth. Environments with greater munificence lay fewer restricts on firms than those environments with resource restricts (Tushman and Anderson, 1986, p. 445).

Environmental munificence is positively related to variety of strategies and choices available to the firm. Empirical results support the view that firms operating with high munificent environments have less competitive pressures (Adegbite et. al., 2018, p. 17). Organizational environment is a major risk source for company. Environmental features have significant implications for businesses in all these areas, including management, strategy, processes and outputs. Therefore, the environmental context is an important determinant of the suitability of rational strategic decision-making processes (Goll and Rasheed, 1997, p. 583-584).

Change in the external environment has an impact on the innovativeness of organizations (Antoncic and Hisrich, 2001, p. 503). In fact, the firm's ability to innovate is considered as the most important factor for competitive advantage in highly dynamic market conditions (Rajapathirana and Hui, 2018, p. 44). Chang and colleagues (2012) argue that, internal organization structures of organizations in an extremely dynamic environment reveal the usefulness of innovation. Moreover, it has been found that innovation is the relationship between organizational and environmental forces and firm performance is mediated in part (Chang et. al., 2012).

\subsection{Firm Performance}

Performance is expressed as the effort of employees in an organization when they are performing their duties. For this reason, firms' success is directly proportional to their employees' performance (Y1ldiz et. al., 2014, p. 787). Firm performance refers to the level of success that the organization achieves through its strategies, efforts or activities at the end of a particular period (Porter, 1991). Fuentes et al. (2004) indicate that organizational performance consists of three dimensions (financial, operational and employee performance). They considered that, organization's environment such as dynamism, munificence, and complexity may have influence on its performance. Also, Venkatraman and Ramanujam (1986) argued that, business performance is multiple hierarchical structures including operational performance (such as market share and quality) and financial performance.

There are many studies in the literature that examine the relationship between innovation and firm performance. Innovativeness has a direct impact on organizational performance (Rajapathirana and Hui, 2018 , p. 46). Yildiz and colleagues (2014) argued that, innovation has a positive influence on business performance. Firm's innovation efforts, despite market dynamism, act as an important determinant of business performance. At the same time, the innovation process is seen as a driving force to increase the institution's innovativeness and performance.

In the light of the literature, we argue that market dynamism increases the firm performance through the positive environment conditions and we propose the following hypothesis:

H1: There is a positive relationship between each of the research variables and firm performance.

H2: Positive environmental conditions mediate the relationship between market dynamism and firm performance.

H3: Positive environmental conditions mediate the relationship between market dynamism and firm innovativeness.

H4: Firm innovativeness mediates the relationship among market dynamism, positive environmental conditions and firm performance.

\section{Research Method}

\subsection{Sample and Data Collection}

The study was conducted in Turkey. The aim of the study was to investigate the effects of positive environment conditions and firm innovativeness on the relationship between market dynamism and firm performance. In this study, we gathered data from a sample of 327 people who work in regional, national, international and global companies, and data were gathered by meeting the people face-to-face or via email. The collected data were analysed by the SPSS statistical package program. Factor analysis, correlation analysis, reliability tests, means of the variables and regression analysis were run to analyse the relationship among variables of the research model. The frequencies of demographic variables were analysed after that the average and standard deviations were calculated. The results were presented in Tables.

The constructs in our study were developed by using measurement scales, which were adopted from prior studies. All of them were measured by five-point Likert scales ranging from (1) strongly agree to (5) strongly disagree. Data were collected from the employees working in companies belonging to distinct sectors (Manufacturing Industry 79.8\%; Service Industry $14.1 \%$ and Information Sector 6.1\%). Respondents' age range mostly varied between $28-40$ with $59.3 \%$. The lowest rate for respondents' age range belonged to individuals older than 41 with $12.7 \%$. On the other hand, $36.8 \%$ of the participants were staff, while senior management had a rate of $8.3 \%$. Other respondents accounted for $54,9 \%$. About three quarters of participants (78.4\%) had at least an undergraduate degree. Lastly, 
$30.9 \%$ of respondent were females, while $69.1 \%$ of respondent were males.

\subsection{Analyses}

To measure market dynamism, we used a 4 items scale developed by Zahra and Garvis (2000) as well as Goll and Rasheed (1997). To measure firm innovativeness, we used a 4 items scale developed by Hult et al. (2004). We measured firm performance in two dimensions: market performance and operational performance. To measure firm performance, we used a 2 items market performance scale adapted from Rahman and Bullock (2005) and a 5 items operational performance scale adapted from Fuentes et al. (2004). Further, to measure positive environment conditions, we used a 3 items scale adapted from Fuentes et al. (2004).

Table 1 illustrates the reliabilities, mean, standard deviations and correlations for the variables in the study. Overall, 18 items using 5 Likert-type scale are used to measure market dynamism, positive environment condition, firm innovativeness and firm performance. Hence, as can be seen along the diagonal of the correlation matrix, each scale has a satisfactory reliability of Cronbach's Alpha above 0,70. The correlation matrix of the variables shows that, all variables are significant and correlated among themselves.

Table 1: Correlations Means, Standard Deviations, Reliabilities

\begin{tabular}{|c|c|c|c|c|c|c|c|c|}
\hline $\begin{array}{l}4 \\
\vdots \\
4\end{array}$ & $\frac{1}{4}$ & 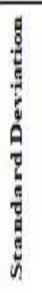 & $\begin{array}{l}0 \\
0 \\
0\end{array}$ & 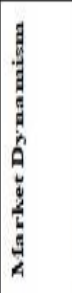 & 员 & $\begin{array}{l}8 \\
8 \\
8 \\
4\end{array}$ & $\begin{array}{l}0 \\
0 \\
0\end{array}$ & : \\
\hline Jarket Dynamism & 3.56 & 76 & 4 & $(0.70)$ & & & & \\
\hline $\begin{array}{l}\text { Positire Enriroument } \\
\text { Conditions }\end{array}$ & 3.76 & 71 & 3 & $388^{88}$ & $(0.71)$ & & & \\
\hline Firm Innorativeneses & 399 & 64 & 4 & $.177^{88}$ & $299^{88}$ & $(0.79)$ & & \\
\hline $\begin{array}{l}\text { Operational } \\
\text { Performance }\end{array}$ & 3.86 & 68 & 5 & $.138^{8}$ & $.250^{88}$ & $.465^{88}$ & $(0.87)$ & \\
\hline Jarket Performance & 4.02 & 75 & 2 & $.145^{88}$ & $.243^{88}$ & $3966^{88}$ & $.432^{88}$ & $(0.72$ \\
\hline
\end{tabular}

** Correlation is significant at the 0.01 level (2tailed).

* Correlation is significant at the 0.05 level (2-tailed).

\section{Findings}

In this study, regression analysis is also conducted to test the hypothesis and to define the direction of relations. When we examine Table 2, it can be seen that, market dynamism and positive environment conditions have significant effects on firm performance and firm innovativeness. According to the Table 2, there is a significant relationship between market dynamism and positive environmental conditions $(\beta=, 380 ; p=, 000)$, operational performance $(\beta=, 138 ; p=, 013)$ and market performance $(\beta=, 145 ; p=, 009)$. Also, there is a significant relationship between positive environmental conditions and operational performance $(\beta=, 250 ; p=, 000)$, market performance $(\beta=, 243 ; p=, 000)$ and firm innovativeness $(\beta=, 291 ; p=, 000)$. Furthermore, regression analysis results show that there is a significant relationship between firm innovativeness and market dynamism $(\beta=, 174 ; p=, 002)$, operational performance $(\beta=, 465$; $\mathrm{p}=, 000)$ and market performance $(\beta=, 396 ; \mathrm{p}=, 000)$. According to the results of our study, there is a positive relationship between each of the research variables and firm performance. So, $\mathrm{H} 1$ is supported according to regression analyses. Also, regression analyses 4, 7 and 10 show that, positive environment conditions have significant effects on firm performance and firm innovativeness. So, $\mathrm{H} 2$ is supported according to regression analyses. Moreover, in the regression analyses, it is seen that positive environment conditions mediate the relationship between market dynamism and firm innovativeness, which means $\mathrm{H} 3$ is supported. As results of regression analyses 16 and 17 show, when the operational performance is included in the regression analyses, the significant effect of firm innovativeness on market performance can be observed. Based on this issue, the results of the regression analysis in Table 2 show that, firm innovativeness mediates the relationship among market dynamism, positive environment conditions and firm performance. So, H4 is a supported. But, positive environment conditions have a partial mediation effect on the relation among market dynamism, firm innovativeness and firm performance. Lastly, Table 2 shows that market dynamism, positive environment conditions and firm innovativeness have significant effects on firm performance (operational and market performance).

Table 2: Regression Analysis Results



Significance: $* * * \mathrm{p}<0.001 * * \mathrm{p}<0.01 * \mathrm{p}<0.05$ 
In accordance with the regression analysis results, our research model is presented in Figure 1 below:

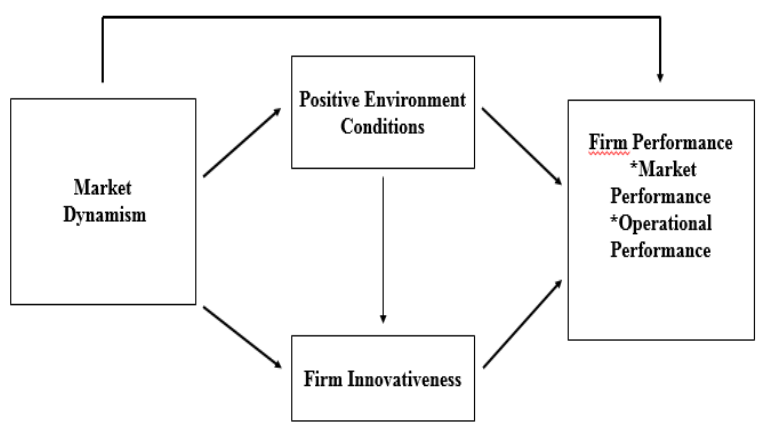

Figure 1. Research Model

\section{Conclusion and Discussions}

This study highlighted the relationship among market dynamism, positive environment conditions, firm innovativeness and firm performance. The results to emerge from data is that, positive environment conditions and firm innovativeness mediate the effect of market dynamism on firm performance. So, H2 (Positive environmental conditions mediate the relationship between market dynamism and firm performance), H3 (Positive environmental conditions mediate the relationship between market dynamism and firm innovativeness) and H4 (Firm innovativeness mediates the relationship among market dynamism, positive environmental conditions and firm performance) are supported.

These results are consistent with the literature, which supports that market dynamism- firm performance relationship can be mediated by other variables which can be external. For example, environmental conditions affect a company's innovation strategy and performance. Thus, the environment is a moderator of the innovation strategy - firm performance link. For Clercq et al., innovation has an important relationship with the financial performance of a firm. They also suggest that, innovation sources and different types are related to performance. According to Oke et al., high research and development expenditures are associated with higher firm performance (Ting, Wang and Wang, 2012, p. 518). Environmental conditions have a dominant influence on the decision-making processes involved in choosing the right strategy, effort or activity (Chang and Hughes, 2012).

On the other hand, in literature review, Tanrıverdi and Zehir's (2006) research results show that a strong and positive correlation among firm innovativeness, operational performance and market performance exist, while there is no significant correlation among any of these variables and market dynamism. Also, empirical studies of organizational innovation show that, there is a positive relationship between innovativeness and firm performance (Calantone et. al., 2002; Damanpour, 1991; Han et. al., 1998; Matsuo, 2006). The reason behind the firm innovativeness-performance relationship is that, innovations function as a coping mechanism for environmental conditions (Matsuo, 2006). For organizations, innovativeness is a means to cope with complexity of the external environment (Han et. al., 1998, p. 35).

In this context, it can be said that the level of market dynamism is a very critical factor in terms of firm performance (Eren, 2012, s. 106). Because, in a dynamic industry, change is inevitable. Firms need to be innovative to protect their speed of change. Thus, a path extending from dynamism to innovation, to performance from innovation can be conditioned by environmental conditions. Environmental conditions that provide a favorable environment for innovative behavior can also affect the relationship between this behavior and firm performance (Thornhill, 2006, p. 691).

Although there are so many studies examining the market dynamism-performance relation (Goll and Rasheed, 1997; Li and Simerly, 1998; Cadogan et. al., 2009; Ikhsan et. al., 2017) and innovativenessperformance relation (Hult et. al., 2004; Thornhill, 2006; Gunday et. al., 2011; Rubera and Kirca, 2012; Rajapathirana and Hui, 2018) in literature; the mediator effects of positive environment conditions and firm innovativeness on the relationship between market dynamism and firm performance are examined and revealed for the first time through that survey, which differentiates this survey from others.

This study contributes literature by showing the importance of positive environment conditions and firm innovativeness on the market dynamism - firm performance relation. With the effective innovativeness strategy, firms can improve capabilities and perform better than their rivals. According to the study of Fuentes's (2004), dynamism and munificence directly influence customer focus, which points to customer satisfaction as the most important requirement for longterm organizational success. In this regard, higher degrees of consumer trends are associated with more frequent changes in environment, and the abundance of resources influences financial performance directly (Fuentes et. al., 2004, p. 436-438).

The dynamics of market conditions in determining the success of an organization play an important role, and firms should not ignore it. Because, any changes in the environment will affect how companies will react to the environment. In other words, environmental conditions will have a contextual effect on the behavior of firm. At the same time, the market conditions can give firms new ideas and motivate them, so that they can respond to environmental changes (Ikhsan et. al., 2017, p. 374).

Lastly, this study has some limitations. First of all, we conducted our survey on firms which operate in and around Istanbul, Turkey. Further researcher can collect data from other countries for the generalizability of results. Also, we used subjective performance measures depending on subjective perceptions of managers. Further research can focus on objective performance measures which are more reliable and precise. 


\section{References}

Adegbite, O. E. (2018). The Organization Business Environment Organizational Adaptations, Springer Briefs in Business, DOI: 10.1007/978-3-319-635101_2

Adler, P. S. and Shenbar, A. (1990). Adapting your technological base: The organizational challenge. Sloan Management Review, 25, 25-37.

Antoncic, B and Hisrich, R. D. (2001). Intrapreneurship: Construct Refinement and Cross-Cultural Validation. Journal of Business Venturing, 16, 495527 .

Auh, S. and Menguc, B. (2005). Top Management Team Diversity and Innovativeness: The Moderating Role of Interfunctional Coordination. Industrial Marketing Management, 34 (3), 249-261.

Cadogan, J. W., Kuivalainen, O., Sundqvist, S. and Sunqvist, S. (2009). Export Market-Oriented Behaviour and Export Performance: Quadratic and Moderating Effects under Differing Degrees of Market Dynamism and Internationalization. Journal of International Marketing, Vol: 17, No: 4, 71-89.

Calantone, R. J., Cavusgil, S. T. and Zhao, Y. (2002). Learning Orientation, Firm Innovation Capability, and Firm Performance. Industrial Marketing Management, 31, 515- 524.

Chang, Y. and Hughes, M. (2012). Drivers of Innovation Ambidexterity in Small-To Medium-Sized Firms. European Management Journal, 30, 1-17.

Chang, Y.; Hughes, M. and Hotho, S. (2011). Internal and external antecedents of SMEs' innovation ambidexterity outcomes. Management Decision, Vol: 49, No: 10, 1658-1676.

Damanpour F. (1991). Organizational Innovation: A Meta-Analysis of Effects of Determinants and Moderators. Academy of Management Journal, 34 (3), 555- 590.

Dess G. G. and Beard DW. (1984). Dimensions of organizational task environments. Administrative Science Quarterly. 1, 52-73.

Eren, S. S. (2012). Stratejik Esneklik ve Pazar Dinamizminin Girişimsel Pazarlama Odaklılığa Etkisi. Journal of Entrepreneurship and Development, 7 (2), 101-112.

Fuentes-Fuentes M. M, Albacete-Saez C. A., LlorensMontes F. J. (2004). The Impact of Environmental Characteristics on TQM Principles and Organizational Performance. Omega-International Journal of Management Science, 32(6), 425-442.

Goll, I. and Rasheed A. M .A. (1997). Rational Decision Making and Firm Performance: The Moderating Role of Environment. Strategic Management Journal, 18 (7), 583- 591.
Gunday, G., Ulusoy, G., Kılıç, K. and Alpkan, L. (2011). Effects of innovation types on firm performance. Int. J. Production Economics, 133, 662-676.

Han, J. K., Kim, N. and Srivastava, R. K. (1998). Market orientation and organizational performance: Is innovation the missing link? Journal of Marketing, 62(4), 30-45.

Homburg, C., Krohmer, H. and Workman, J. P. (1999). Strategic Consensus and Performance: The Role of Strategy Type and Market-Related Dynamism. Strategic Management Journal, Vol: 20, No: 4, 339357.

Hult G., Tomas M., Hurley R. F. and Knight G. A. (2004). Innovativeness: Its antecedents and impact on business performance. Industrial Marketing Management, 33, 429-438.

Ikhsan, K.; Almahendra, R. and Budiarto, T. (2017). Contextual Ambidexterity in SME's In Indonesia: A Study on How it Mediates Organizational Culture and Firm Performance and How Market Dynamism Influences its Role on Firm Performance. International Journal of Business and Society, Vol: 18 No: 2, 369-390.

Laforet, S. (2011). A framework of organizational innovation and outcomes in SMEs. International Journal of Entrepreneurial Behaviour \& Research, 17(4), 380-408.

Lawson, B. and Samson, D. (2001). Developing innovation capability in organisations: A dynamic capabilities approach. International Journal of Innovation Management, 5(03), 377-400.

Li, M. and Simerly, R. L. (1998). The Moderating Effect of Environmental Dynamism on the Ownership and Performance Relationship. Strategic Management Journal, Vol. 19, 169-179.

Lumpkin, G. T. and Dess, G. G. (2001). Linking Two Dimensions of Entrepreneurial Orientation to Firm Performance: The Moderating Role of Environment and Industry Life Cycle. Journal of Business Venturing 16, 429-451.

Matsuo, M. (2006). Customer Orientation, Conflict, and Innovativeness in Japanese Sales Departments. Journal of Business Research, 59, 242-250.

Porter, M.E. (1991). Towards a Dynamic Theory of Strategy. Strategic Management Journal, 12, 95117.

Rahman, S. and Bullock, P. (2005). Soft TQM, Hard TQM and Organisational Performance Relationships: An Empirical Investigation. Omega, $33,73-83$. 
Rajapathirana, R. P. J. and Hui, Y. (2018). Relationship between innovation capability, innovation type, and firm performance. Journal of Innovation \& Knowledge, Vol: 3, 44-55.

Rubera, G. and Kirca, Ahmet H. (2012). Firm Innovativeness and Its Performance Outcomes: A Meta-Analytic Review and Theoretical Integration. Journal of Marketing, Vol. 76, No. 3, 130-147.

Sen, F. K. and Egelhoff, W. G. (2000). Innovative capabilities of a firm and the Use of Technical Alliances. IEEE Transactions on Engineering Management, 47(2), 174-183.

Tanriverdi, H. and Zehir, C. (2006). Impact of Learning Organizations' Applications and Market Dynamism on Organizations' Innovativeness and Market Performance. The Business Review, 6(2), 238-245.

Thornhill, S. (2006). Knowledge, innovation and firm performance in high- and low-technology regimes. Journal of Business Venturing, 21, 687-703.

Ting, H. F., Wang, H. B. and Wang, D. S. (2012). The moderating role of environmental dynamism on the influence of innovation strategy and firm performance. International Journal of Innovation. Management and Technology, Vol. 3, No. 5, 517520 .

Tushman ML. and Anderson P. (1986). Technological discontinuities and organizational environments. Administrative Science Quarterly, 31, 439-465.

Venkatraman, N. and V. Ramanujam (1986). Measurement of business performance in strategy research: A comparison of approaches'. Academy of Management Review, Vol: 11, 801-814.

Yıldız, S, Baştürk, F. and Taştan Boz, I. (2014). The Effect of Leadership and Innovativeness on Business Performance. Procedia Social and Behavioral Sciences, 150, 785-793.

Zahra, S. A. and Garvis, D. M. (2000). International Corporate Entrepreneurship and Firm Performance: The Moderating Effect of International Environmental Hostility. Journal of Business Venturing, 15, 469-492. 